\title{
Candidate Gene Expression in Bos indicus Ovarian Tissues: Prepubertal and Postpubertal Heifers in Diestrus
}

OPEN ACCESS

Edited by:

Ramanathan K. Kasimanickam, Washington State University, USA

Reviewed by: Adriana Santana Carmo,

Deoxi Biotecnologia, Brazil Sherrie Gayle Clark-Deener, Virginia Tech, USA

${ }^{*}$ Correspondence: Marina Rufino S. Fortes

m.fortes@uq.edu.au

tPresent address: Matthew Kelly,

The Australian Agricultural Company, Brisbane, QLD, Australia

Sophia Edwards,

Vetoquinol Australia Pty Ltd, Brisbane, QLD, Australia

Emily Piper,

Zoetis Inc. Pharmaceuticals, Kalamazoo, MI, USA

Specialty section: This article was submitted to Animal Reproduction - Theriogenology,

a section of the journal

Frontiers in Veterinary Science

Received: 25 July 2016 Accepted: 04 October 2016 Published: 18 October 2016

Citation:

Weller MMDCA, Fortes MRS, Porto-Neto $L R$, Kelly $M$, Venus $B$, Kidd L, do Rego JPA, Edwards S,

Boe-Hansen GB, Piper E, Lehnert SA, Guimarães SEF and Moore SS (2016) Candidate Gene Expression in Bos indicus Ovarian

Tissues: Prepubertal and Postpubertal Heifers in Diestrus. Front. Vet. Sci. 3:94. doi: 10.3389/fvets.2016.00094

\author{
Mayara Morena Del Cambre Amaral Weller ${ }^{1,2}$, Marina Rufino S. Fortes ${ }^{3 *}$, \\ Laercio R. Porto-Neto ${ }^{4}$, Matthew Kelly ${ }^{2 \dagger}$, Bronwyn Venus ${ }^{2}$, Lisa Kidd ${ }^{5}$, \\ João Paulo Arcelino do Rego ${ }^{6}$, Sophia Edwards ${ }^{5 \dagger}$, Gry B. Boe-Hansen ${ }^{5}$, Emily Piper ${ }^{5 \dagger}$, \\ Sigrid A. Lehnert ${ }^{4}$, Simone Eliza Facioni Guimarães ${ }^{1}$ and Stephen Stewart Moore ${ }^{2}$
}

\begin{abstract}
${ }^{1}$ Animal Science Department, Universidade Federal de Viçosa, Viçosa, Minas Gerais, Brazil, ${ }^{2}$ Queensland Alliance for Agriculture and Food Innovation, Centre for Animal Science, The University of Queensland, Brisbane, QLD, Australia, ${ }^{3}$ School of Chemistry and Molecular Biosciences, The University of Queensland, Brisbane, QLD, Australia, ${ }^{4}$ CSIRO Agriculture Flagship, Queensland Bioscience Precinct, Brisbane, QLD, Australia, ${ }^{5}$ School of Veterinary Sciences, The University of Queensland, Gatton, QLD, Australia, ${ }^{6}$ Instituto Federal de Educação, Ciência e Tecnologia do Ceará, Fortaleza, Ceará, Brazil
\end{abstract}

Growth factors such as bone morphogenetic proteins $6,7,15$, and two isoforms of transforming growth factor-beta (BMP6, BMP7, BMP15, TGFB1, and TGFB2), and insulin-like growth factor system act as local regulators of ovarian follicular development. To elucidate if these factors as well as others candidate genes, such as estrogen receptor 1 (ESR1), growth differentiation factor 9 (GDF9), follicle-stimulating hormone receptor $(F S H R)$, luteinizing hormone receptor $(L H R)$, bone morphogenetic protein receptor, type 2 (BMPR2), type 1 insulin-like growth factor receptor (IGFR1), and key steroidogenic enzymes cytochrome P450 aromatase and 3- $\beta$-hydroxysteroid dehydrogenase (CYP19A1 and HSD3B1) could modulate or influence diestrus on the onset of puberty in Brahman heifers, their ovarian mRNA expression was measured before and after puberty (luteal phase). Six postpubertal (POST) heifers were euthanized on the luteal phase of their second cycle, confirmed by corpus luteum observation, and six prepubertal (PRE) heifers were euthanized in the same day. Quantitative real-time PCR analysis showed that the expression of FSHR, BMP7, CYP19A1, IGF1, and IGFR1 mRNA was greater in PRE heifers, when contrasted to POST heifers. The expression of $L H R$ and HSD3B1 was lower in PRE heifers. Differential expression of ovarian genes could be associated with changes in follicular dynamics and different cell populations that have emerged as consequence of puberty and the luteal phase. The emerging hypothesis is that BMP7 and IGF1 are co-expressed and may modulate the expression of FSHR, LHR and IGFR1, and CYP19A1. BMP7 could influence the downregulation of $L H R$ and upregulation of FSHR and CYP19A1, which mediates the follicular dynamics in heifer ovaries. Upregulation of IGF1 expression prepuberty, compared to postpuberty diestrus, correlates with increased levels FSHR and CYP19A1. Thus, BMP7 and IGF1 may play synergic roles and were predicted to interact, from the expression data $(P=0.07, r=0.84)$. The role of these co-expressed genes in puberty and heifers luteal phase merits further research.

Keywords: bovine species, intraovarian factors, quantitative real-time PCR, corpus luteum, folliculogenesis 


\section{INTRODUCTION}

Ovarian activity and hormones are paramount for pubertal development and normal reproductive performance (1). Improving the reproductive performance of Bos indicus cattle is an industry priority in tropical and subtropical regions of the world, because of its impact on farm productivity (2). B. indicus breeds have a later onset of puberty (16-40 months of age), which has a negative impact on their overall reproductive performance (3-6). Although the heritability of age at puberty measured by first detected corpus luteum (CL) has been reported to be moderate $(0.52-0.57)$ (7), the phenotypic identification of animals that undergo puberty at an early age is expensive. Enhancing our comprehension of ovarian genes and their interactions involved in bovine puberty could have practical implications in the animal breeding context.

The regulation of ovarian activity is an integrated process that involves FSH and $\mathrm{LH}$, their receptors, ovarian steroids, and intraovarian factors (8). Some of the most important intraovarian factors are members of the transforming growth factor-beta (TGFB) superfamily, such as bone morphogenetic proteins (BMPs) 6, 7, and 15 (BMP6, BMP7, and BMP15) and two isoforms of TGFB (TGFB1 and TGFB2), which are expressed by ovarian somatic cells and oocytes in a stage-specific manner throughout folliculogenesis $(9,10)$. These genes function as local regulators of ovarian follicular development and subsequently affect fertility (11-13). Experiments in mice indicate that the different isoforms of TGFB are responsible for diverse physiological functions $(14,15)$. An in vivo study showed that $B M P 7$ promotes the "recruitment" of primordial follicles into the growing follicle pool while inhibiting progesterone production and ovulation (16). Similar to $B M P 7, B M P 15$, and $B M P 6$ are part of a group of luteinization inhibitors (17). In vitro, BMP7 induced expression of follicle-stimulating hormone receptor (FSHR) mRNA in human granulosa cells (18). In contrast, BMP15 suppressed FSHR and luteinizing hormone receptor ( $L H R)$ expression (19). Given the discussed roles affecting ovulation, these intraovarian factors could modulate or influence the onset of puberty that leads to the first ovulation event.

Growth differentiation factor 9 (GDF9) gene expression is relevant for oocyte competence, and GDF9 follows a similar expression pattern to BMP15 in cows stimulated with FSH treatment (20). The relevance of GDF9 expression in ovarian tissues of peripubertal $B$. indicus heifers is unclear, but its link to $B M P 15$ and FSH pathways merits investigation.

The insulin-like growth factors (IGFs) system plays a key role in follicular development and female fertility (21-23). Insulinlike growth factor 1 (IGF1) and insulin-like growth factor 2 (IGF2) have been reported to act in synergy with gonadotropins LH and FSH to stimulate growth and differentiation of ovarian follicles and subsequent synthesis and secretion of estradiol and progesterone production (24-27). Moreover, experiments in cattle $(28,29)$ showed that IGF2 was the main intrafollicular IGF ligand regulating follicular growth and highly expressed in theca cells. All of these previous reports suggest that the IGFs and TGFB superfamily genes may have different roles in ovarian activity, related to the cycle phase and possible to endocrine regulation of puberty.
Estrogen produced by ovarian tissue in relevant for GnRH release from the hypothalamus and the expression of its receptor, ESR1, has been associated with puberty in mice (30). In cattle, ESR1 expression is required for normal follicular development and follicular dominance (31). Given the relevance of steroid hormones for pubertal development and ovarian function, key steroidogenic enzymes such as cytochrome P450 aromatase (CYP19A1) and 3- $\beta$-hydroxysteroid dehydrogenase (HSD3B1) were also targeted in this study.

So far, studies have focused on the endocrine regulation of the hypothalamic-pituitary-ovarian system for onset of puberty (32-34). Information about specific changes in ovarian gene expression-associated specific cycle phases and puberty is sparse. Thus, the aim of the present study was to elucidate the expression pattern of candidate genes, such as ESR1, GDF9, FSHR, LHR, BMPR2, TGFB1, TGFB2, BMP15, BMP6, BMP7, IGF1, IGFR1, IGF2, CYP19A1, and HSD3B1 in pre- (PRE) and postpubertal (POST) heifers in the diestrus phase. Evidence of differential expression will help to support or disprove the hypothesis that these genes modulate or are influenced by the presence of circulating progesterone and the onset of puberty.

\section{MATERIALS AND METHODS}

\section{Animal Management and Puberty Observation}

Management, handling, and euthanasia of animals were approved by the Animal Ethics Committee of The University of Queensland, Production and Companion Animal group (certificate number QAAFI/279/12). Twenty Brahman heifers, which were not pedigree animals, but had a characteristic $B$. indicus phenotype and were typical beef industry animals, were sourced as young weaners born at the same season $(<250 \mathrm{~kg})$ and kept at grazing conditions, from two commercial herds in Queensland, Australia. After being sourced, heifers were kept at the Gatton Campus facilities of the University of Queensland; they were all under the same conditions and pasture based diet until project end. Precise day of birth information was not available for these heifers as they were sourced from industry; the effect of age differences in pubertal development is possible but could not be tested in this experiment.

Heifers were examined every 2 weeks for observation of pubertal development, from October 2012 to May 2013. Ovarian activity was observed using ultrasonography [HS-2000(VET), Honda Electronics Inc.]. Pubertal status was defined by presence of a CL observed with the ultrasound (7). Euthanasia plans were based on date of the first CL observation. Six heifers were chosen to be prepubertal (PRE) and six heifer POST. The POST heifer when identified was then paired with PRE heifer which was randomly drawn from the remaining animals and processed on the same day. The animals were weighted, and the body condition (BCS) was measured. POST heifers were euthanized 23 days, on average, after observation of the first CL. POST heifers were euthanized on the luteal phase of their second estrous cycle, confirmed by CL presence on ovarian tissue post euthanasia. Euthanasia was carried out by stunning with a non-penetrating 
captive bolt followed by exsanguination. Concentrations of progesterone were measured with a radioimmunoassay (RIA) from blood samples collected at exsanguination, to confirm that POST heifers had a functional CL, which was observed at euthanasia. RIA was performed by the Laboratory for Animal Endocrinology of the University of Queensland (Dr. Stephen Anderson). Plasma progesterone concentrations were measured by RIA as described by J. D. Curlewis, M. Axelson, and G. M. Stone (35) with the difference that progesterone antiserum C-9817 (Bioquest, North Ryde, NSW, Australia) was used. Extraction efficiency was $75 \%$, and the values reported herein were not corrected for these losses. The sensitivity of the assay was $0.1 \mathrm{ng} / \mathrm{ml}$, and the intra- and interassay coefficient of variation (CV) was $5.0 \%$.

Post-euthanasia, left and right ovaries were harvested and preserved by snap freezing in liquid nitrogen, then kept at $-80^{\circ} \mathrm{C}$ until RNA extractions were carried out. In total, 24 ovaries $(2 \times 6$ PRE and $2 \times 6$ POST heifers) were processed separately for RNA extraction and quantitative real-time PCR (qRT-PCR) measurements.

\section{RNA Extraction and Quantitative Real-Time Transcription PCR Analysis}

Prior to RNA extraction, the whole ovary tissue was ground under liquid nitrogen to form a powder of which $25 \mathrm{mg}$ was used for RNA extractions; left and right ovaries were kept separately. Total RNA was isolated separately from $25 \mathrm{mg}$ of the homogenized sample of left and right ovaries from PRE and POST heifers, using Trizol method (Life Technologies, Inc.). The total RNA was resuspended in RNase-free ultrapure water and stored at $-80^{\circ} \mathrm{C}$ until further use. RNA concentrations were measured by Nanodrop ND-1000 spectrophotomer (Thermo Fisher Scientific, Wilmington, DE, USA) with an optimal 260/280 ratio between 1.8 and 2.1. Intact $28 \mathrm{~S}$ and $18 \mathrm{~S}$ rRNA subunit integrity was assessed by Bioanalyser (RIN 6.9 or above for all samples).

Reverse transcription was performed using GoScript Reverse Transcription System (Promega) and oligo (dT) primers (Invitrogen). The reactions were performed with $6 \mu \mathrm{g}$ of total RNA and $2 \mu \mathrm{l}$ of $50 \mu \mathrm{M}$ oligo (dT) $23 \mathrm{VN}$ primer, following the manufacturer's recommended protocol. The cDNA concentrations from the samples were estimated on a Nanodrop ND-1000 spectrophotomer (Thermo Fisher Scientific). Finally, the singlestranded cDNA samples were stored at $-20^{\circ} \mathrm{C}$ until analysis by qRT-PCR.

Quantitative real-time PCR reactions were performed in triplicate using SYBR ${ }^{\circledR}$ Select Master Mix (Applied Biosystem) following the manufacturer's instructions in a ViiA ${ }^{\mathrm{TM}} 7$ Real-Time PCR System (Applied Biosystem). The CV of Ct values from replicates within each sample was low $<3 \%$ indicating acceptable accuracy and reproducibility (not shown). The oligonucleotide primers used for the reactions were designed using PrimerQuest software provided by Integrated DNA Technologies, Inc. from Bos taurus sequences available in GeneBank database. In the present study, glyceraldehyde 3-phosphate dehydrogenase $(G A P D H)$ was used as an internal control gene because it was stably expressed in our study and previously in dairy cattle (36). The list of primer sequences used for each target gene is listed in Table 1.
Prior to performing qRT-PCR, the amplification efficiency and optimal primer concentration were determined for each gene using serial dilution of cDNA. For this purpose, four concentrations of cDNA $(0.625,2.5,10$, and $40 \mathrm{ng} /$ reaction) and two primer dilutions $(100,200 \mathrm{nM})$ were tested. The PCR efficiencies for all primers pairs were obtained using the formula $E=10^{(-1 / \text { slope })} \times 100$, where $E$ is efficiency and slope is the gradient of dilution series in the linear phase. These results are summarized in Table 1, where $E$ is represented as a percentage $[\% E=(E-1) \times 100]$. Samples were amplified separately in triplicate using a ViiA ${ }^{\mathrm{TM}} 7$ Real-Time PCR System (Applied Biosystem, Foster City, CA, USA) with the following amplification program: an initial step at $95^{\circ} \mathrm{C}$ for $10 \mathrm{~min}$, a second step of 40 cycles of $95^{\circ} \mathrm{C}$ for $20 \mathrm{~s}$, and a final extension step at $60^{\circ} \mathrm{C}$ for $30 \mathrm{~s}$. At the end of each reaction, a denaturation curve was plotted to assure that each reaction produced a single fragment, that is, the curve contained only one dissociation peak.

\section{Statistical Analysis}

Progesterone, body weight, and condition score data were analyzed in a completed randomized design using SAS (version 9.1.3), and means were compared by the $t$-test to the level of $5 \%$. Statistical analysis of Ct data was performed using \%QPCR_MIXED macro developed in SAS (version 9.1.3) (https://msu.edu/ steibelj/ JP_files/QPCR.html) developed to generate codes in SAS PROC MIXED suitable to analyze data from qRT-PCR, assuming independent random effects for reference and target genes in each biological replicate (37). The following model was used:

$$
y_{g i k r}=\mathrm{TG}_{g i}+\mathrm{C}_{g i k}+\mathrm{D}_{i k}+\mathrm{e}_{g i k r}
$$

where, $y_{\text {gikr }}$ corresponds to the Ct value obtained from the thermocycler software for the gth gene (reference or targets) from the $r$ th well, which corresponds to the $k$ th animal in $i$ th physiological state (PRE or POST); $\mathrm{TG}_{g i}$ is the effect of the $i$ th physiological state on the expression of gene g; $\mathrm{C}_{g i k} \sim \mathrm{N}\left(0, \sigma_{\mathrm{C}}^{2}\right)$ is the genespecific random effect of the $k$ th animal; $\mathrm{D}_{i k} \sim N\left(0, \sigma_{\mathrm{D}}^{2}\right)$ is the sample-specific random effect (common to reference and target genes); and $\mathrm{e}_{\text {gikr }} \sim N\left(0, \sigma_{\mathrm{e}}^{2}\right)$ is the residual term.

The relative expression was estimated using $\Delta \mathrm{Ct}$ method (target gene $\mathrm{Ct}$ - GAPDH gene $\mathrm{Ct}$ ) as previously reported (38), where $\mathrm{Ct}$ is the PCR cycle number at which the fluorescence generated within a reaction crosses an arbitrary threshold. For each target gene, the comparison of gene expression between physiological state (PRE or POST) was performed by CONTRAST statement of the GLM procedure (SAS software) using Student's $t$-test to the level of $5 \%$. The "estimates" generated by CONTRAST analyses were used to estimate fold-change (relative expression) for pair-wise contrast of interest and were obtained by using $2^{\text {-(Estimate) }}$. The contrast between PRE versus POST heifers (both ovaries) was analyzed considering the average of $\mathrm{Ct}$ values from right and left ovary of each heifer for each gene. The other two contrasts were: (1) both ovaries from PRE versus only ovaries with CL from POST heifers and (2) ovaries from POST heifers without CL versus ovaries from POST heifers with CL. These two other contrasts should help to elucidate if differences in gene expression observe are related to the local presence of the 
TABLE 1 | Gene names, primer pair sequences, annealing temperatures, and amplification efficiencies of each target.

\begin{tabular}{|c|c|c|c|c|}
\hline Gene $^{a}$ & GenBank accession no. & Primer sequence $\left(5^{\prime}-3^{\prime}\right)$ & Amplicon (bp) & Efficiency (\%) \\
\hline \multirow[t]{2}{*}{ ESR1 } & NM_001001443.1 & F-СTCTCTGCCTITGCTACCTTAC & 114 & 98.87 \\
\hline & & R-CCCGGGTCACAAATAGCTAAA & & \\
\hline \multirow[t]{2}{*}{ FSHR } & NM_174061.1 & F-CATGCTCATCTTCACCGACTT & 112 & 99.64 \\
\hline & & R-GACCAGGAGGATCTITGACTTG & & \\
\hline \multirow[t]{2}{*}{ LHR } & NM_174381.1 & F-GAGTGGCTGGGATTATGACTATG & 127 & 99.87 \\
\hline & & R-CAGCCAAATCAGGACTCTAAGG & & \\
\hline \multirow[t]{2}{*}{ BMPR2 } & NM_001304285.1 & F-GTACCGGCATGACCACTATATC & 120 & 99.74 \\
\hline & & R-AGTCTTCTTCGGTCAGTTGTAAG & & \\
\hline \multirow[t]{2}{*}{ TGFB1 } & NM_001166068.1 & F-TGCTTCAGCTCCACAGAAA & 149 & 99.74 \\
\hline & & R-GTATCCAGGCTCCAGATGTAAG & & \\
\hline \multirow[t]{2}{*}{ TGFB2 } & NM_ 001113252.1 & F-CACGAATGGCTCCACCATAA & 127 & 98.67 \\
\hline & & R-AGCGTGCTTCTAGTTCTTCAC & & \\
\hline \multirow[t]{2}{*}{ GDF9 } & NM_174681.2 & F-GCATTCCСTCCACССTAAA & 113 & 99.89 \\
\hline & & R-GGTGACGGGACAATCTTACA & & \\
\hline \multirow[t]{2}{*}{ BMP15 } & NM_001031752.1 & F-GTAGTGAGGTTCGTGAGTTCTG & 111 & 98.85 \\
\hline & & R-TAGGGAGAGGTTGGTCTTCT & & \\
\hline \multirow[t]{2}{*}{ BMP6 } & XM_005223892.2 & F-TTCTCAACGACGCCGATATG & 122 & 98.56 \\
\hline & & R-ACCCTCAGGAATCTGGGATAG & & \\
\hline \multirow[t]{2}{*}{ BMP7 } & NM_001206015.1 & F-ATGACAGCTCCAACGTCATC & 123 & 98.99 \\
\hline & & R-AGAGACCCAGGATCCAGAAA & & \\
\hline \multirow[t]{2}{*}{ CYP19A1 } & NM_174305.1 & F-GTGTCCGAAGTTGTGCCTAT & 101 & 98.95 \\
\hline & & R-GACCTGGTATTGAGGATGTGTC & & \\
\hline \multirow[t]{2}{*}{ HSD3B1 } & NM_174343.3 & F-ACACCAGCACCATAGAAGTG & 113 & 98.88 \\
\hline & & R-CTTGCTGTATGGGTATGGAGAG & & \\
\hline \multirow[t]{2}{*}{ IGF1 } & NM_001077828.1 & F-TCCCATCTCССTGGATTTCT & 105 & 98.86 \\
\hline & & R-GGGTTGGAAGACTGCTGATT & & \\
\hline \multirow[t]{2}{*}{ IGFR1 } & NM_001244612.1 & F-GTATGGAGGAGCCAAGCTAAA & 123 & 98.98 \\
\hline & & R-GTCTTGGCCTGAACGTAGAA & & \\
\hline \multirow[t]{2}{*}{ IGF2 } & NM_174087.3 & F-CATTGTGGGAAGGTGTGTC & 113 & 99.02 \\
\hline & & R-TTACATTCTGTGGGCTGTGG & & \\
\hline \multirow[t]{2}{*}{$B 2 M$} & NM_173893.3 & F-ACCTGAACTGCTATGTGTATGG & 134 & 99.95 \\
\hline & & R-GTGGGACAGCAGGTAGAAAG & & \\
\hline \multirow[t]{2}{*}{ GAPDH } & NM_001034034.2 & F-GATGCTGGTGCTGAGTATGT & 113 & 99.96 \\
\hline & & R-GCAGAAGGTGCAGAGATGAT & & \\
\hline
\end{tabular}

${ }^{a}$ Gene symbol: ESR1, estrogen receptor $\alpha$; FSHR, follicle-stimulating hormone receptor; LHR, luteinizing hormone receptor; BMPR2, bone morphogenetic protein receptor, type 2; TGF $\beta 1$, transforming growth factor beta 1; TGF 32 , transforming growth factor beta 2; GDF9, growth differentiation factor 9; BMP15, bone morphogenetic protein 15; BMP6, bone morphogenetic protein 6; BMP7, bone morphogenetic protein 7; CYP19A1, cytochrome P450 aromatase; HSD3B1, 3- $\beta$-hydroxysteroid dehydrogenase; IGF1, insulin-like growth factor 1; IGFR1, type 1 insulin-like growth factor receptor; IGF2, insulin-like growth factor 2; B2M, beta-2-macroglobulin; GAPDH, glyceraldehyde-3-phosphate dehydrogenase.

CL itself or not (are more generally related to PRE versus POST processes). Once the efficiency $(E)$ of the qRT-PCR reaction was close to $100 \%$, one PCR cycle of difference between two samples means twice as much expression in the first sample in comparison with the second.

Pair-wise correlations between gene expression values were calculated, and its significance was tested using $\mathrm{R}$ software for analyses. Significant correlations were interpreted as predicted gene interactions.

\section{RESULTS}

\section{Serum Progesterone Concentrations, Body Weight, and Condition}

Average serum concentration of progesterone for the PRE and POST B. indicus Brahman heifers were $0.4 \pm 0.2$ and $2.0 \pm 0.7 \mathrm{ng} /$ $\mathrm{ml}$, respectively ( $n=6$ per group). The difference in progesterone concentration corresponds to the observation of CL in POST heifers. Associated data collected prior to euthanasia of PRE and POST heifers indicated no significant difference in body weight or body condition score between PRE and POST heifers. Body weight averages were $338 \pm 54.17$ and $362.6 \pm 38.62 \mathrm{~kg}(P=0.38)$, and condition score averages were $3.5 \pm 0.44$ and $3.75 \pm 0.41$ $(P=0.18)$, respectively.

\section{Ovarian Gene Expression}

Ovarian gene expression was measured with real-time quantitative PCR in three contrasts: (1) average gene expression from both ovaries PRE versus POST heifers in diestrus; (2) average expression of PRE ovaries versus only ovaries with a CL in POST heifers in distrus; and (3) ovaries with CL versus ovaries without using only POST heifers in diestrus.

In the contrast between PRE versus POST heifers (both ovaries), FSHR $(P<0.05)$, BMP7 $(P<0.05)$, IGF1 $(P<0.05)$, TGFB1 $(P<0.01)$, and IGFR1 $(P<0.01)$ expression were greater in PRE heifers, whereas $\operatorname{LHR}(P<0.05)$ expression was lower in PRE heifers (Figure 1). The abundance of key steroidogenic enzyme genes, such as CYP19A1 $(P<0.05)$ was greater in PRE heifers, whereas HSD3B1 mRNA expression was greater $(P<0.01)$ in POST heifers. 


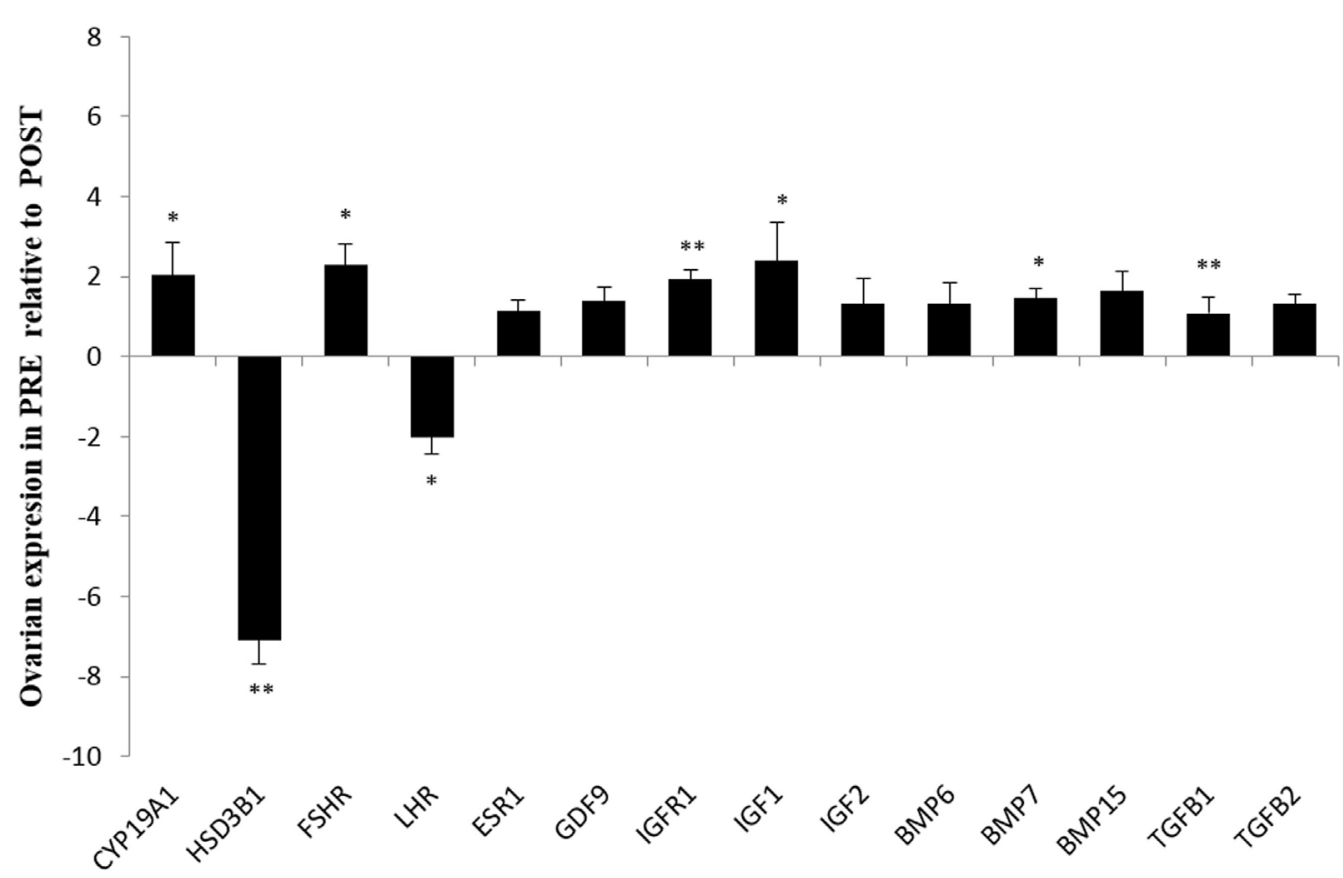

FIGURE 1 | Relative expression values for each candidate gene in both ovaries from prepubertal (PRE) heifers versus both ovaries from postpubertal

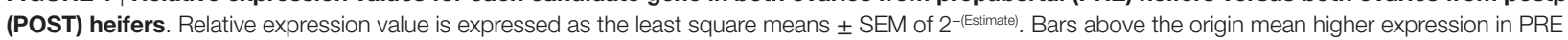
compared to POST. ${ }^{\star} P<0.05 ;{ }^{\star \star} P<0.01$.

In the contrast between both ovaries from PRE versus only ovaries with CL from POST heifers, FSHR $(P<0.05)$, CYP19A1 $(P<0.05)$, and TGFB1 $(P<0.01)$ expression was greater in PRE heifers, whereas expression of LHR $(P<0.05)$, and HSD3B1 $(P<0.01)$ were greater in POST heifers' ovaries with CL (Figure 2).

In the third and last contrast, we did not observe any differential gene expression between ovaries with a CL versus the contralateral ovary (without CL) from POST heifers (not shown).

Pair-wise correlations predicted four gene-gene interactions from co-expression data. The predicted significant correlations were between: LHR and HSD3B1 $(P<0.01, r=-0.97)$; and HSD3B1 and CY19A1 $(P=0.03, r=-0.90)$. Correlations between IGF1 and BMP7 $(P=0.07, r=0.84)$; IGF1 and IGFR1 $(P=0.10$, $r=0.79)$ were high $(r>0.79)$ but not statistically significant $(P>0.05$ and $<0.10)$. Other pair-wise correlations between gene expression values were low and not significant $(P>0.1)$.

\section{DISCUSSION}

This study has demonstrated that the diestrus phase of pubertal heifers is associated with changes in ovarian gene expression of gonadotropin receptors (FSHR and $L H R$ ), key steroidogenic enzymes (HSD3B1 and CYP19A1) and important intraovarian factors and their receptor, such as BMP7, TGFB1, and IGFR1. The regulation of ovarian activity is determined by coordinated action between FSH and $\mathrm{LH}$ with their receptors, ovarian steroids, and intraovarian factors (8). Genes of the TGFB superfamily, such as GDF9, BMP6, BMP7, BMP15, TGFB1, and $T G F B 2$, and their cell receptors are known paracrine and autocrine modulators of ovarian function and fertility (9-13). The IGF system plays a key role in follicular development and is an additional important intraovarian factor involved in pubertal development $(24-27,39)$. Our results fit with current theory and point to specific intraovarian factors relevant to the diestrus phase of pubertal heifers in $B$. indicus.

We did not detect differential gene expression between ovaries from POST heifers with a CL versus the contralateral ovary (without a CL), which could confirm the systemic effect of circulating progesterone on ovarian dynamics. Therefore, we focused on the differences between PRE and POST heifers. In the present study, the significant differences in ovarian gene expression between two physiological states, PRE and POST (luteal phase), are likely related to onset of puberty and influenced by progesterone signaling. It is important to note that the comparison is between PRE heifers, which had never experienced a luteal phase and the related progesterone signaling, while the POST heifers were in their second diestrus with the corresponding levels of progesterone being produced by CL. Future research examining the other phases of the cycle in POST heifers would complement our findings.

We identified greater expression of FSHR in the ovaries of PRE than POST heifers in diestrus, which could be related to follicular waves characterized by synchronous development of groups of growing follicles, one of which would became dominant and achieved the greatest diameter, suppressing the growth of the other smaller subordinate follicles. Transrectal ultrasonography has detected the sequential growth and regression of large follicles in heifers, near the time of first ovulation (40). FSH and its receptor FSHR play an important role in follicle progression from 


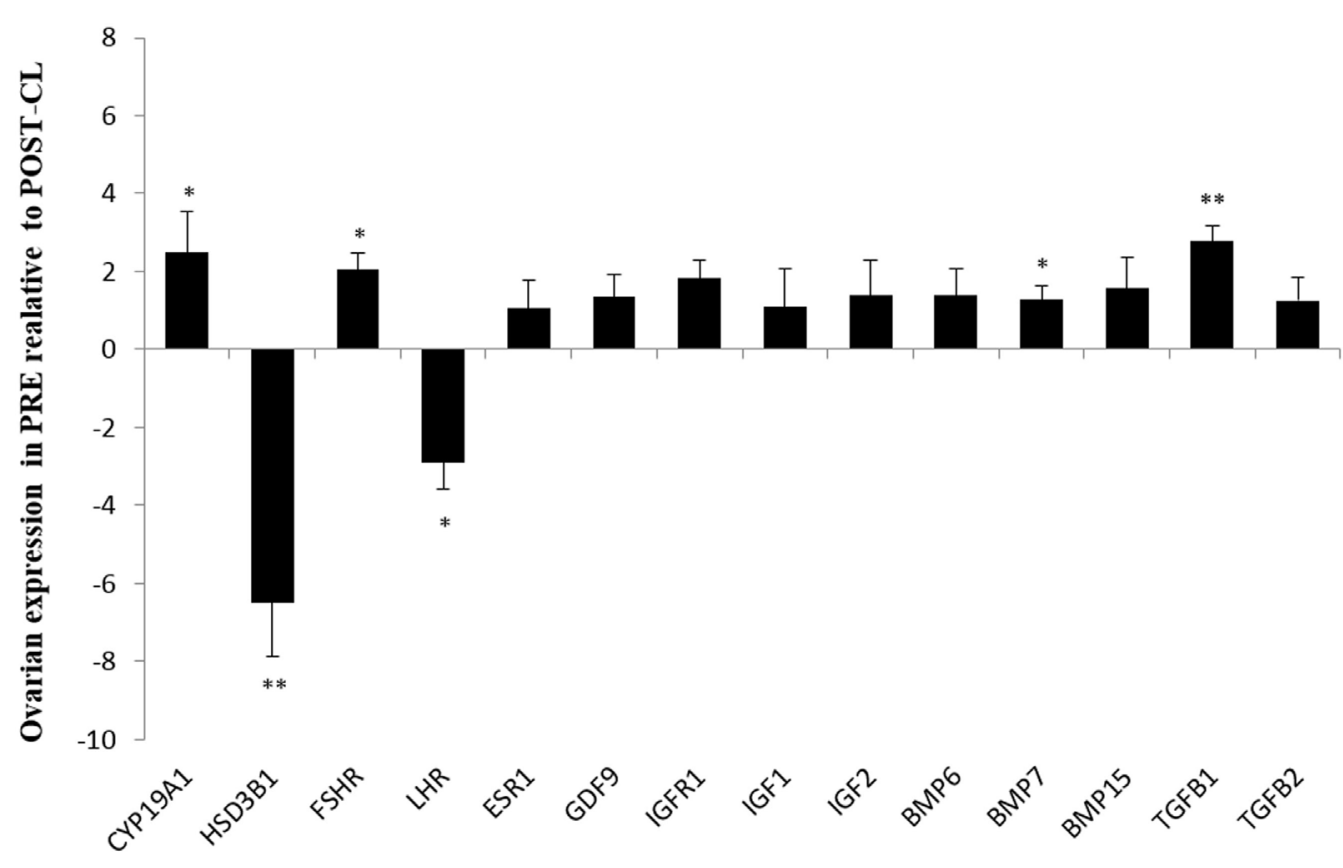

FIGURE 2 | Relative expression values for each candidate gene in both ovaries from prepubertal (PRE) heifers versus only the ovary with corpus luteum of the postpubertal (POST-CL) heifers. Relative expression value is expressed as the least square means \pm SEM of $2^{-(E s t i m a t e)}$. Bars above the origin mean higher expression in PRE compared to POST with CL. ${ }^{\star} P<0.05 ;{ }^{\star \star} P<0.01$.

the primary to the advanced stage of follicular development (41). Studies reported the expression of FSHR on granulosa cells in primary and secondary follicles, which is evidence for the role of FSH in follicular development at early stages $(41,42)$. Our findings are further supported by previous studies that demonstrated an increase in FSH binding sites in the rat ovary during the PRE period $(43,44)$. The lower expressions of FSHR in POST heifers in diestrus is in accord with the higher progesterone concentrations during luteal phase because progesterone exerts a negative feedback inhibition on $\mathrm{GnRH}$ and suppress further follicular growth and maturation (45).

The POST heifers in diestrus exhibited greater LHR mRNA expression than PRE heifers. These animals are in luteal phase of their estrous cycle, and it is well know that LH has essential role for maintenance and normal function of the CL (46). Therefore, LHR signaling is likely to play has an essential role in suppressing ovarian activity in the remainder of the diestrus ovary.

The BMPs are important for the regulation of follicular development, ovulation, and CL morphogenesis (12, 16, 19). Interestingly, in the present study, no significant differences in mRNA abundance of GDF9, BMP15, BMP6 TGFB2, and their receptor $B M P R 2$ were observed between the PRE versus POST contrasts. Although these genes are known as modulators of mammalian folliculogenesis and were therefore selected for investigation, it seems they are not involved with the changes in follicular dynamics observed in this contrast of PRE versus POST (luteal phase). The specific BMP associated with diestrus and pubertal development seems to be BMP7.

In the PRE versus POST (luteal phase) contrast, BMP7 was differentially expressed. Our findings demonstrated higher abundance of ovarian BMP7 in PRE than in POST heifers, which may be associated with the different physiological phases represented in this contrast. The ovaries of PRE heifers are likely to be constantly initiating in follicular recruitment. The recruitment stage is characterized by the presence of a cohort of growing follicles at the beginning of the follicular wave. Our finding is consistent with previous studies in mice and human showing that BMP7 promoted the recruitment of primordial follicles into the growing follicles and enhanced estradiol secretion when secretion of progesterone was concomitantly suppressed $(9,47,48)$. Because progesterone is important in the process of ovulation (49), inhibition of progesterone production by BMP7 suggests a functional role as luteinization inhibitor delaying ovulation $(50,51)$. Furthermore, in an in vitro study, BMP7 increased FSHR mRNA expression in rat and human granulosa cells (18, 52), while it decreased $L H R$ expression in human granulosa cells (18). In this context, the results of the present study suggest an important mechanism of FSHR and LHR regulation by BMP7 in PRE heifers. Greater ovarian BMP7 contributes to increased FSH sensitivity of granulosa cells via upregulation of FSHR and downregulation of $L H R$, thus promoting folliculogenesis (recruitment, selection, and atresia) and suppressing ovulation (18).

We observed differential expression of key steroidogenic genes CYP19A1 and HSD3B1 between PRE and POST heifers. CYP19A1 codes for the key regulator enzyme in the steroid biosynthesis pathways: P450aromatase, which catalyzes the conversion of androgens to estrogens (53). The upregulation of BMP7 may explain the increased expression of CYP19A1 in PRE heifers when compared to the diestrus POST heifers. An in vivo study demonstrated that rat ovaries treated with BMP7 
had enhanced expression of CYP19A1, which in turn increased estradiol production, as well as increased the number of preantral and antral follicles $(47,54)$.

Greater expression of HSD3B1 mRNA in POST heifers in their luteal phase could be the result of the presence of an active CL and consequent progesterone signaling. Theca- and granulosaderived luteal cells express the enzyme HSD3B1 that converts pregnenolone to progesterone (55). In short, the greater expression of HSD3B1 is necessary for production of progesterone, which is generally not occurring in PRE heifers.

Transforming growth factor-beta isoforms (TGFB1and TGFB2) are multifunctional regulatory molecules because it can either stimulate or inhibit proliferation, differentiation, and other critical cell functions according to species, stage of differentiation of ovarian cells, and presence of others growth factors $(48,56,57)$. In rodents, TGFB1 increased proliferation of FSHstimulated granulosa cells (58). However, in cattle (TGFB2) and sheep (TGFB1 and TGFB2), these growth factors have inhibitory effects on granulosa cell proliferation $(59,60)$. The effect of TGFB isoforms are species specific and might be different in $B$. indicus and $B$. taurus animals. TGFB1 mRNA and protein expression in bovine granulosa cells decrease during progress of folliculogenesis (61). Furthermore, in cattle, TGFB1 was present in granulosa cells of earliest stage of development (early preantral and early antral follicles) but absent in larger more advanced follicles (62). We observed greater expression of TGFB1 mRNA in PRE heifers compared to POST heifers (luteal phase), which highlights the important role of TGFB1 in modulating both granulosa cell growth and differentiation. We can speculate that the proliferation inhibition induced by TGFB1 may promote differentiation of granulosa cell in order to acquire FSHR and express steroidogenic enzymes, which allow the cell to be more responsive to FSH and enables secretion of ovarian steroids. An improved understanding of the mechanisms of TGFB1 in follicular growth and pubertal development in bovine ovary requires further investigation. Especially, it will be relevant to understand the interactions between BMP7 and TGFB1 in regulation of bovine folliculogenesis. To achieve a better understanding of this interaction, it will be relevant to study the expression of BMP7 and TGFB1 in all phases of the estrus cycle for POST heifers.

Intrafollicular IGF1 and IGF2 have been reported to act in synergy with the gonadotropins LH and FSH to stimulate growth and differentiation of ovarian follicles and subsequent synthesis and secretion of estradiol and progesterone production (24-27). The type 1 IGF receptor (IGFR1) mediates most of the actions of both IGF1 and IGF2 (63), and its expression increases during follicular development (64). In this current study, we observed greater expression of IGF1 and IGFR1 in PRE compared to POST heifers (luteal phase). Our findings suggest that IGF1, as well as BMP7, could be underpinning the increased expression of FSHR and CYP19A1 mRNA found in PRE heifers ovaries. This is in agreement with a previous in vivo study that showed IGF1 can regulate FSHR gene expression and indirectly aromatase expression (65). FSHR expression has been shown to be severely reduced in preantral follicles of IGF1 knockout mice, as well as aromatase expression, and was restored to wild-type expression levels after
2 weeks of exogenous IGF1 supplementation (66). Reinforcing this hypothesis an in vivo study showed that FSH enhanced IGFR1 expression (65). Thus, local IGF1 creates a positive feedback loop where IGF1 enhances FSH action and FSH enhances IGF1 action through mutual receptor upregulation.

Taken together, our findings suggest that BMP7 and IGF1 may interact and regulate intrafollicular steroidogenesis and follicular response to gonadotropins during pubertal development. The emerging hypothesis is that two regulators of ovarian activity prepuberty are co-expressed: BMP7 and IGF1. These two genes may play synergic roles modulating the expression of $F S H R, L H R$, and IGFR1, and steroidogenesis (CYP19A1). BMP7 could be associated with downregulation of $L H R$ and upregulation of FSHR and CYP19A1, which mediates the follicular dynamics in PRE heifer ovaries as compared to POST (luteal phase). Upregulation of IGF1 expression in PRE compared to POST (luteal phase) correlates with increased levels FSHR and CYP19A1. Furthermore, TGFB1 likely plays important role in follicular dynamics in prepuberty. The role of these genes and predicted interactions merits further research to elucidate the molecular pathways in cattle ovarian tissue, pre- and postpuberty, especially to elucidate these genes expression in all cycle phases.

In summary, our results suggest that differential expression of ovarian genes could be related to changes in follicular dynamics and differences of gene expression levels within the cell population that formed the ovarian tissue, which had emerged as consequence of the luteal phase and puberty. The comparative expression of these genes in granulosa versus luteal cells in cattle PRE versus POST (including all cycle phases) should be the focus of further research to better understand their role in puberty. The data presenting herein are a starting point that reinforces the differentially expressed genes as relevant genes for ovarian dynamics in $B$. indicus heifers.

\section{AUTHOR CONTRIBUTIONS}

MW, MF, LP-N, SL, and SM participated in the design of the study. MF, LP-N, LK, JR, SE, GB-H, and EP carried the field trial and euthanasia of heifers. BV contributed to handling of tissue samples and RNA extraction. MW performed qRT-PCR experiment. MW and MK performed statistical analyses. MW, MF, SG, GB-H, SL, and SM drafted and revised the manuscript. All authors read and approved the final manuscript.

\section{ACKNOWLEDGMENTS}

The authors gratefully acknowledge The University of Queensland (UQ) in permitting the study to be performed and the Animal Genetics Laboratory (AGL at UQ) for their technical support.

\section{FUNDING}

Financial support for this Ph.D. project was provided by The University of Queensland and Coordenação de Aperfeiçoamento de Pessoal de Nível Superior (CAPES/project number A125/2013). MF is supported by the UQ Postdoctoral Fellowship. 


\section{REFERENCES}

1. Bliss SP, Navratil AM, Xie J, Roberson MS. GnRH signaling, the gonadotrope and endocrine control of fertility. Front Neuroendocrinol (2010) 31(3):322-40. doi:10.1016/j.yfrne.2010.04.002

2. Burrow HM. Importance of adaptation and genotype $x$ environment interactions in tropical beef breeding systems. Animal (2012) 6(5):729-40. doi:10.1017/S175173111200002X

3. Abeygunawardena $\mathrm{H}$, Dematawewa CM. Pre-pubertal and postpartum anestrus in tropical Zebu cattle. Anim Reprod Sci (2004) 8(2-83):373-87. doi:10.1016/j.anireprosci.2004.05.006

4. Burns BM, Fordyce G, Holroyd RG. A review of factors that impact on the capacity of beef cattle females to conceive, maintain a pregnancy and wean a calf-implications for reproductive efficiency in northern Australia. Anim Reprod Sci (2010) 122(1-2):1-22. doi:10.1016/j.anireprosci.2010.04.010

5. Nogueira GP. Puberty in South American Bos indicus (Zebu) cattle. Anim Reprod Sci (2004) 8(2-83):361-72. doi:10.1016/j.anireprosci.2004.04.007

6. Brito LF, Silva AE, Unanian MM, Dode MA, Barbosa RT, Kastelic JP. Sexual development in early- and late-maturing Bos indicus and Bos indicus x Bos taurus crossbred bulls in Brazil. Theriogenology (2004) 62(7):1198-217. doi:10.1016/j.theriogenology.2004.01.006

7. Johnston DJ, Barwick SA, Corbet NJ, Fordyce G, Holroyd RG, Williams PJ, et al. Genetics of heifer puberty in two tropical beef genotypes in Northern Australia and associations with heifer- and steer-production traits. Anim Prod Sci (2009) 49(6):399-412. doi:10.1071/EA08276

8. Van den Hurk R, Zhao J. Formation of ovarian follicles and their growth, differentiation and maturation within ovarian follicles. Theriogenology (2005) 63(6):1717-51. doi:10.1016/j.theriogenology.2004.08.005

9. Knight PG, Glister C. TGF-beta superfamily members and ovarian follicle development. Reproduction (2006) 132(2):191-206. doi:10.1530/rep.1.01074

10. Otsuka F. Multiple endocrine regulation by bone morphogenetic protein system. Endocr J (2010) 57(1):3-14. doi:10.1507/endocrj.K09E-310

11. Corduk N, Abban G, Yildirim B, Sarioglu-Buke A. The effect of vitamin D on expression of TGF betal in ovary. Exp Clin Endocrinol Diabetes (2012) 120(8):490-3. doi:10.1055/s-0032-1314858

12. Nagashima T, Kim J, Li Q, Lydon JP, DeMayo FJ, Lyons KM, et al. Connective tissue growth factor is required for normal follicle development and ovulation. Mol Endocrinol (2011) 25(10):1740-59. doi:10.1210/me.2011-1045

13. Paradis F, Novak S, Murdoch GK, Dyck MK, Dixon WT, Foxcroft GR. Temporal regulation of BMP2, BMP6, BMP15, GDF9, BMPR1A, BMPR1B, BMPR2 and TGFBR1 mRNA expression in the oocyte, granulosa and theca cells of developing preovulatory follicles in the pig. Reproduction (2009) 138(1):115-29. doi:10.1530/REP-08-0538

14. Proetzel G, Pawlowski SA, Wiles MV, Yin M, Boivin GP, Howles PN, et al. Transforming growth factor-beta 3 is required for secondary palate fusion. Nat Genet (1995) 11:409-14. doi:10.1038/ng1295-409

15. Sanford LP, Ormsby I, Gittenberger-de Groot AC, Sariola H, Friedman R, Boivin GP, et al. TGFbeta 2 knockout mice have multiple developmental defects that are nonoverlapping with other TGFbeta knockout phenotypes. Development (1997) 124(13):2659-70.

16. Otsuka F, Moore RK, Shimasaki S. Biological function and cellular mechanism of bone morphogenetic protein-6 in the ovary. J Biol Chem (2001) 276(35):32889-95. doi:10.1074/jbc.M103212200

17. Otsuka F, Yamamoto S, Erickson GF, Shimasaki S. Bone morphogenetic protein-15 inhibits follicle-stimulating hormone (FSH) action by suppressing FSH receptor expression. J Biol Chem (2001) 276(14):11387-92. doi:10.1074/ jbc.M010043200

18. Shi J, Yoshino O, Osuga Y, Nishii O, Yano T, Taketani Y. Bone morphogenetic protein 7 (BMP-7) increases the expression of follicle-stimulating hormone (FSH) receptor in human granulosa cells. Fertil Steril (2010) 93(4):1273-9. doi:10.1016/j.fertnstert.2008.11.014

19. Shimasaki S, Moore RK, Otsuka F, Erickson GF. The bone morphogenetic protein system in mammalian reproduction. Endocr Rev (2004) 25(1):72-101. doi:10.1210/er.2003-0007

20. Barros CM, Satrapa RA, Castilho AC, Fontes PK, Razza EM, Ereno RL, et al. Effect of superstimulatory treatments on the expression of genes related to ovulatory capacity, oocyte competence and embryo development in cattle. Reprod Fertil Dev (2012) 25:17-25. doi:10.1071/RD12271
21. Adashi EY, Roban RM. Intraovarian regulation: peptidergic signalling systems. Trends Endocrinol Metab (1992) 3(7):243-8. doi:10.1016/1043-2760 (92)90125-K

22. Armstrong DG, Webb R. Ovarian follicular dominance: the role of intraovarian growth factors and novel proteins. Rev Reprod (1997) 2(3):139-46. doi:10.1530/ror.0.0020139

23. Giudice LC. Insulin-like growth factors and ovarian development. Endocr Rev (1992) 13(4):641-69. doi:10.1210/edrv-13-4-641

24. Bergh C, Olsson JH, Hillensjo T. Effect of insulin-like growth factor I on steroidogenesis in cultured human granulosa cells. Acta Endocrinol (1991) 125(2):177-85. doi:10.1530/acta.0.1250177

25. Adashi EY, Resnick CE, Brodie AM, Svoboda ME, Van Wyk JJ. SomatomedinC-mediated potentiation of follicle-stimulating hormone-induced aromatase activity of cultured rat granulosa cells. Endocrinology (1985) 117(6):2313-20. doi:10.1210/endo-117-6-2313

26. Spicer LJ, Aad PY. Insulin-like growth factor (IGF) 2 stimulates steroidogenesis and mitosis of bovine granulosa cells through the IGF1 receptor: role of follicle-stimulating hormone and IGF2 receptor. Biol Reprod (2007) 77(1):18-27. doi:10.1095/biolreprod.106.058230

27. Veldhuis JD, Rodgers RJ. Mechanisms subserving the steroidogenic synergism between follicle-stimulating hormone and insulin-like growth factor I (somatomedin C). Alterations in cellular sterol metabolism in swine granulosa cells. J Biol Chem (1987) 262(16):7658-64.

28. Perks CM, Peters AR, Wathes DC. Follicular and luteal expression of insulin-like growth factors I and II and the type 1 IGF receptor in the bovine ovary. J Reprod Fertil (1999) 116(1):157-65. doi:10.1530/jrf.0.1160157

29. Armstrong DG, Gutierrez CG, Baxter G, Glazyrin AL, Mann GE, Woad KJ, et al. Expression of mRNA encoding IGF-I, IGF-II and type 1 IGF receptor in bovine ovarian follicles. JEndocrinol (2000) 165(1):101-13. doi:10.1677/ joe. 0.1650101

30. Cheong RY, Czieselsky K, Porteous R, Herbison AE. Expression of ESR1 in glutamatergic and GABAergic neurons is essential for normal puberty onset, estrogen feedback, and fertility in female mice. J Neurosci (2015) 35:14533-43. doi:10.1523/JNEUROSCI.1776-15.2015

31. Rovani MT, Gasperin BG, Ilha GF, Ferreira R, Bohrer RC, Duggavathi R, et al. Expression and molecular consequences of inhibition of estrogen receptors in granulosa cells of bovine follicles. J Ovarian Res (2014) 7:96. doi:10.1186/ s13048-014-0096-0

32. Evans AC, Adams GP, Rawlings NC. Endocrine and ovarian follicular changes leading up to the first ovulation in prepubertal heifers. J Reprod Fertil (1994) 100(1):187-94. doi:10.1530/jrf.0.1000187

33. Nakada K, Moriyoshi M, Nakao T, Watanabe G, Taya K. Changes in concentrations of plasma immunoreactive follicle-stimulating hormone, luteinizing hormone, estradiol-17beta, testosterone, progesterone, and inhibin in heifers from birth to puberty. Domest Anim Endocrinol (2000) 18(1):57-69. doi:10.1016/S0739-7240(99)00063-6

34. Ojeda SR, Dubay C, Lomniczi A, Kaidar G, Matagne V, Sandau US, et al. Gene networks and the neuroendocrine regulation of puberty. Mol Cell Endocrinol (2010) 324(1-2):3-11. doi:10.1016/j.mce.2009.12.003

35. Curlewis JD, Axelson M, Stone GM. Identification of the major steroids in ovarian and adrenal venous plasma of the brush-tail possum (Trichosurus, Vulpecula) and changes in the peripheral plasma-levels of estradiol and progesterone during the reproductive-cycle. J Endocrinol (1985) 105:53-62. doi:10.1677/joe.0.1050053

36. Weller MM, Fortes MRS, Marcondes MI, Rotta PP, Gionbeli TR, Valadares Filho SC, et al. Effect of maternal nutrition and days of gestation on pituitary gland and gonadal gene expression in cattle. J Dairy Sci (2016) 99:3056-71. doi:10.3168/jds.2015-9673

37. Steibel JP, Poletto R, Coussens PM, Rosa GJM. A powerful and flexible linear mixed model framework for the analysis of relative quantification RT-PCR data. Genomics (2009) 94(2):146-52. doi:10.1016/j.ygeno.2009. 04.008

38. Livak KJ, Schmittgen TD. Analysis of relative gene expression data using realtime quantitative PCR and the 2 DDCT method. Methods (2001) 25(4):402-8. doi:10.1006/meth.2001.1262

39. Fortes MR, Li Y, Collis E, Zhang Y, Hawker RJ. The IGF1 pathway genes and their association with age of puberty in cattle. Anim Genet (2013) 44(1):91-5. doi:10.1111/j.1365-2052.2012.02367.x 
40. Roche JF, Boland MP. Turnover of dominant follicles in cattle of different reproductive states. Theriogenology (1991) 35(1):81-90. doi:10.1016/0093691X(91)90149-8

41. Richards JS. Hormonal control of gene expression in the ovary. Endocr Rev (1994) 15(6):725-51. doi:10.1210/edrv-15-6-725

42. Bao B, Garverick HA, Smith GW, Smith MF, Salfen BE, Youngquist RS. Changes in messenger RNA encoding LH receptor, cytochrome P450 side chain cleavage, and aromatase are associated with recruitment and selection of bovine ovarian follicles. Biol Reprod (1997) 56(5):1158-68. doi:10.1095/ biolreprod56.5.1158

43. Tanaka Y, Nakada K, Moriyoshi M, Sawamukai Y. Appearance and number of follicles and change in the concentration of serum FSH in female bovine foetuses. Reproduction (2001) 121(5):777-82. doi:10.1530/rep.0. 1210777

44. Peluso B, Steger RW, Hafez ESE. Development of gonadotrophin-binding sites in the immature rat ovary. J Reprod Fertil (1976) 47:55-8. doi:10.1530/ jrf.0.0470055

45. Sokka T, Huhtaniemi I. Ontogeny of gonadotrophin receptors and gonadotrophin stimulated cyclic AMP production in the neonatal rat ovary. J Endocrinol (1990) 127:297-303. doi:10.1677/joe.0.1270297

46. Webb R, Gong JG, Law AS, Rusbridge SM. Control of ovarian function in cattle. J Reprod Fertil Suppl (1992) 5:141-56.

47. Niswender GD, Juengel JL, Silva PJ, Rollyson MK, McIntush EW. Mechanisms controlling the function and life span of the corpus luteum. Physiol Rev (2000) $80(1): 1-29$.

48. Lee WS, Otsuka F, Moore RK, Shimasaki S. Effect of bone morphogenetic protein-7 on folliculogenesis and ovulation in the rat. Biol Reprod (2001) 65(4):994-9. doi:10.1095/biolreprod65.4.994

49. Zhang H, Klausen C, Zhu H, Chang HM, Leung PC. BMP4 and BMP7 suppress StAR and progesterone production via ALK3 and SMAD1/5/8-SMAD4 in human granulosa-lutein cells. Endocrinology (2015) 156(11):4269-80. doi:10.1210/en.2015-1494

50. Yoshimura Y, Wallach EE. Studies of the mechanism(s) of mammalian ovulation. Fertil Steril (1987) 47(1):22-34. doi:10.1016/S0015-0282(16)49931-0

51. Shimasaki S, Zachow RJ, Li D, Kim H, Iemura S, Ueno N, et al. A functional bone morphogenetic protein system in the ovary. Proc Natl Acad Sci U S A (1999) 96(13):7282-7. doi:10.1073/pnas.96.13.7282

52. Findlay JK, Drummond AE, Dyson ML, Baillie AJ, Robertson DM, Ethier JF. Recruitment and development of the follicle; the roles of the transforming growth factor-b superfamily. Mol Cell Endocrinol (2002) 191(1):35-43. doi:10.1016/S0303-7207(02)00053-9

53. Lee WS, Yoon SJ, Yoon TK, Cha KY, Lee SH, Shimasaki S, et al. Effects of bone morphogenetic protein-7 (BMP-7) on primordial follicular growth in the mouse ovary. Mol Reprod Dev (2004) 69(2):159-63. doi:10.1002/mrd.20163

54. Meinhardt U, Mullis PE. The essential role of the aromatase/p450arom. Semin Reprod Med (2002) 20(3):277-84. doi:10.1055/s-2002-35374

55. Gougeon A. Human ovarian follicular development: from activation of resting follicles to preovulatory maturation. Ann Endocrinol (2010) 71(3):132-43. doi:10.1016/j.ando.2010.02.021

56. Hanukoglu I. Steroidogenic enzymes: structure, function, and role in regulation of steroid hormone biosynthesis. J Steroid Biochem (1992) 43(8):779-804. doi:10.1016/0960-0760(92)90307-5
57. Lerner AA, Salamone DF, Chiappe ME, Baranao JL. Comparative studies between freshly isolated and spontaneously immortalized bovine granulosa cells: protein secretion, steroid metabolism, and responsiveness to growth factors. JCell Physiol (1995) 164(2):395-403. doi:10.1002/ jcp.1041640220

58. Juengel JL, McNatty KP. The role of proteins of the transforming growth factor-beta superfamily in the intraovarian regulation of follicular development. Hum Reprod Update (2005) 11(2):143-60. doi:10.1093/humupd/ dmh061

59. Saragueta PE, Lanuza GM, Baranao JL. Autocrine role of transforming growth factor b1 on rat granulosa cell proliferation. Biol Reprod (2002) 66(6):1862-8. doi:10.1095/biolreprod66.6.1862

60. Gilchrist RB, Morrissey MP, Ritter LJ, Armstrong DT. Comparison of oocyte factors and transforming growth factor-b in the regulation of DNA synthesis in bovine granulosa cells. Mol Cell Endocrinol (2003) 201(1-2):87-95. doi:10.1016/S0303-7207(02)00429-X

61. Juengel JL, Bibby AH, Reader KL, Lun S, Quirke LD, Haydon LJ, et al. The role of transforming growth factor-b (TGF-b) during ovarian follicular development in sheep. Reprod Biol Endocrinol (2004) 2:78-88. doi:10.1186/14777827-2-78

62. Nilsson EE, Doraiswamy V, Skinner MK. Transforming growth factor-beta isoform expression during bovine ovarian antral follicle development. Mol Reprod Dev (2003) 66(3):237-46. doi:10.1002/mrd.10350

63. Oullette Y, Price CA, Carrière PD. Follicular fluid concentration of transforming growth factor-betal is negatively correlated with estradiol and follicle size at the early stage of development of the first-wave cohort of bovine ovarian follicles. Domest Anim Endocrinol (2005) 29(4):623-33. doi:10.1016/ j.domaniend.2005.04.008

64. Lucy MC. Regulation of ovarian follicular growth by somatotropin and insulin-like growth factors in cattle. J Dairy Sci (2000) 83(7):1635-47. doi:10.3168/jds.S0022-0302(00)75032-6

65. Wandji SA, Pelletier G, Sirard MA. Ontogeny and cellular localization of 125I-labeled insulin-like growth factor-I, 125I-labeled follicle-stimulating hormone, and 125I-labeled human chorionic gonadotropin binding sites in ovaries from bovine fetuses and neonatal calves. Biol Reprod (1992) 47(5):814-22. doi:10.1095/biolreprod47.5.814

66. Zhou J, Chin E, Bondy CA. Cellular pattern of IGF-I and IGF-I receptor gene expression in the developing and mature follicle. Endocrinology (1991) 129(6):3281-8. doi:10.1210/endo-129-6-3281

Conflict of Interest Statement: The authors declare that the research was conducted in the absence of any commercial or financial relationships that could be construed as a potential conflict of interest.

Copyright (๑) 2016 Weller, Fortes, Porto-Neto, Kelly, Venus, Kidd, do Rego, Edwards, Boe-Hansen, Piper, Lehnert, Guimarães and Moore. This is an open-access article distributed under the terms of the Creative Commons Attribution License (CC BY). The use, distribution or reproduction in other forums is permitted, provided the original author(s) or licensor are credited and that the original publication in this journal is cited, in accordance with accepted academic practice. No use, distribution or reproduction is permitted which does not comply with these terms. 